\title{
Analysis of Scientific Productivities on the Three Most Famous Outbreaks of Betacoronavirus Genus: SARS, MERS and COVID-19
}

\author{
En Ünlü Üç Betakoronavirüs Salgınılla Ilgili BilimseI Verimlilik Analizi: SARS, MERS ve COVID-19
}

\author{
Koray Bas', Fulya Yılmaz ${ }^{2}$ \\ ${ }^{1}$ General Surgery Clinic; ${ }^{2}$ Anesthesiology and Reanimation Clinic, Izmir Bozyaka Training and Research Hospital, Health Sciences \\ University, Izmir, Turkey
}

\section{ABSTRACT}

Aim: The 21st Century has already witnessed three outbreaks caused by the same family of coronaviruses, the Severe Acute Respiratory Syndrome (SARS), the Middle East Respiratory Syndrome (MERS) and recently, The Noval Coronavirus Disease 2019 (COVID-19).

The main aim of this study is to analyze the overall scientific publications indexed in Science Citation Index Expanded (SCI-E) about these three outbreaks. And the secondary aim is to compare first scientific reactions to SARS, MERS and COVID-19 outbreaks in their early phases by using the dates of first 4 months of them.

Material and Method: Web of Science (WoS) software was used for the search and the analysis. Allscientific papers, included in SCI-E, related with each outbreaks of SARS, MERS and COVID-19 from 1980 to April15.2020, were searched and analyzed by using the terms of "SARS", "SARS-CoV" and "Severe Acute Respiratory Syndrome" for SARS; "MERS", "MERS-CoV", "HCoV-EMC" and "Middle East Respiratory Disease" for MERS and "COVID-19", "2019-n-CoV", "SARS-CoV-2", "Coronavirus disease 19" and "2019 novel coronavirus" for COVID-19 in the topic section of the software.

Results: Overall; 3690, 1517 and 730 papers, indexed by SCI-E, were found related to SARS, MERS and COVID-19 respectively. The biggest contribution for publications was from People's Republic of China (PRC) for SARS and COVID-19 and was from The United States of America (USA) for MERS.

Conclusion: In this study, it was revealed that scientific contribution to COVID-19 is faster and greatful then SARS and MERS in the early phase of the outbreak. But the pandemic potential of betacoronaviruses, especially SARS-CoV-2, remains a threat for public health globally. Therefore further research into the pathogenesis of these infections in order to find appropriate targets for treatment is imperative.

Key words: SARS; MERS; COVID-19; SARS-COV; MERS-CoV; HCOV-EMC; SARS-CoV2

\section{ÖZET}

Amaç: 21. yüzyıl, aynı koronavirüs ailesinin neden olduğu üç salgına, Șiddetli Akut Solunum Sendromu (SARS), Orta Doğu Solunum Sendromu (MERS) ve yakın zamanda Noval Koronavirüs Hastalığı 2019'un (COVID-19) tanık olmuștur. Bu çalıșmanın amacı, bu üç salgın ile ilgili, Science Citation Index Expanded (SCI-E) dergilerde indekslenen genel bilimsel yayınları analiz etmektir. İincil amacı ise SARS, MERS ve COVID-19 salgınlarına yönelik ilk bilimsel reaksiyonları erken evrelerinde, ilk 4 aylık süreçlerinde, karșılaștırmaktır.

Materyal ve Metot: Arama ve analiz için ISI-Web of KnowledgeWeb of Science (WoS) yazılımı kullanılmıștır. 1975'ten 15 Nisan 2020'ye kadar SARS, MERS ve COVID-19 salgını ile ilgili SCI-E indexlenen tüm bilimsel makaleler Șiddetli Akut Solunum Sendromu (SARS) için "SARS", "SARS-CoV" ve "Șiddetli Akut Solunum Sendromu" terimleri kullanılarak; Orta Doğu Solunum Sendromu (MERS) için "MERS", "MERS-CoV", "HCoV-EMC" ve "Orta Doğu Solunum Sendromu" terimleri kullanılarak ve COVID-19 için "COVID-19", "2019-n-CoV", "SARS-CoV-2", "Koronavirüs hastalığı 19" ve "2019 yeni koronavirüs" erimleri kullanılarak arștırma yapıldı.

Bulgular: SCI-E tarafindan indekslenen 3690 yayın SARS ile, 1517 yayın MERS ile ve 730 yayın COVID-19 ile ilgili bulunmuștur. Yayınlara en büyük katkı, SARS ve COVID-19 için Çin Halk Cumhuriyeti'nden (PRC); MERS için Amerika Birleșik Devletlerindendir (ABD).

Sonuç: Bu çalıșma ile, COVID-19'a bilimsel katkının salgının erken evresindeki SARS ve MERS'den daha hızlı ve daha büyük olduğunu gösterdik. Ancak, HCoV'lerin, özellikle SARS-CoV-2'nin pandemik potansiyeli, küresel olarak halk sağlığı için bir tehdit olmaya devam etmektedir. Bu nedenle, tedavi için uygun hedefleri bulmak için HCoV enfeksiyonlarının patogenezine yönelik daha fazla araștırma yapılması zorunludur.

Anahtar kelimeler: SARS; MERS; COVID-19; SARS-COV; MERS-COV; HCOV-EMC; SARS-CoV2

IIetișim/Contact: Fulya Yilmaz, Saglik Bilimleri Universitesi Izmir Bozyaka Egitim ve Arastirma Hastanesi Anesteziyoloji ve Reanimasyon Klinigi, Izmir, Turkey • Tel:05335110505・E-mail:fulya.dr@gmail.com • Geliș/Received: 19.09.2020 • Kabul/Accepted: 9.12.2020

ORCID: Koray Baş, 0000-0001-7911-0218 • Fulya Yilmaz, 0000-0002-6901-7404 


\section{Introduction}

The 21 st Century has already witnessed three outbreaks caused by the same family of coronaviruses, the Severe Acute Respiratory Syndrome (SARS) and the Middle East Respiratory Syndrome (MERS) ${ }^{1,4}$ and recently, in December 2019 the Noval Coronavirus Disease 2019 (COVID-19) ${ }^{4-6}$.

SARS was first recognised in Foshan, Guangdong, China in November 16th, $2002^{6}$ and remained in the population for the following 8 months until July 2003. During the SARS outbreak, a total of 8098 suspected SARS cases from 29 countries was identified and a total of 916 SARS related deaths was reported ${ }^{1,3,7-12}$ with the mortality rate of $11 \%^{8,13,14}$ by The World Health Organisation (WHO). Most cases were in Asia, mainly in China, Europe and North America ${ }^{6}$.

Aproximately a decade later the emergence of SARS, MERS outbreak occurred in theKingdom of Saudi Arabia in 2012. According to WHO reports, MERS spread over 27 countries, infected 2254 patients and lead to 800 MERS related death ${ }^{3}$ with the fatality rate of $34 \% \%^{4,8,14}$.

And recently, COVID-19 first appeared in Wuhan, China in late December 20195,6,15. The symptom onset date of the first identified patient infected by SARSCoV-2, the virus responsable for COVID-19, was December 1 st, $2019^{16}$ and the first case confirmed on 7 th December 2019. On $31^{\text {st }}$ December 2019, a new coronavirus infection was identified ${ }^{6}$ and than China notified the outbreak ${ }^{8}$. On 30th January 2020, WHO declared the COVID-19 outbreak as "a health emergency of international concern" ${ }^{4,5}$. And regarding the last update of WHO Covid-19 Outbreak Situation website on April 19th 2020, there were 2,203,927 confirmed cases and 148,749 confirmed deaths over 213 countries, areas or territories globally ${ }^{17}$.

The main aim of this study is to analyze the overall scientific publications indexed in SCI-E about three outbreaks of SARS, MERS and COVID-19, all of which caused by the viruses from the same coronavirus genus. And the secondary aim is to compare first scientific reactions to SARS, MERS and COVID-19 outbreaks in their early phases.

\section{Materials and Methods}

WoS software was used for the search and the analysis. All scientific works, included in Science Citation Index Expanded (SCI-E), related with each outbreaks of SARS, MERS and COVID-19 from the beginning of 1980, the earliest day software allowed to search, to April 15, 2020, the date of the study, were searched by using the terms of "SARS", "SARS-CoV" and "Severe Acute Respiratory Syndrome" for SARS; "MERS", "MERS-CoV", "HCoV-EMC" and "Middle East Respiratory Disease" for MERS and "COVID-19", "2019-n-CoV”, "SARS-CoV-2", "Coronavirus disease 19" and "2019 novel coronavirus" for COVID-19 in the topic section of the software. We applied an advanced search by using search operators of WoS as AND, OR and NOTto reduce overlapping papers which included the same terms.

We further analyzed the results of each searches by the "analyze" function of the software in terms of number of papers for each country, type of documentation, number of publications per year, name of journals and authors. The number of citations to published works was also calculated by using the citation function of the same software for each outbreak.

\section{Results}

Overall; 3690, 1517 and 730 papers, indexed by SCI-E, were found related to SARS, MERS and COVID-19 between 1980 and April 15.2020 respectively. Publications were dominantly in English.

Outbreaks were first recognised in November 2002, in June 2012 and late December 2019 for SARS, MERS and COVID-19 respectively. Number of publications in early phase of outbreaks, in their first 4 months, was 10 for SARS and 730 for COVID-19. Up to November 2012, there was no publication in SCI-E journals about MERS (Table 1). Number of publications per year for outbreaks was reported in Figure 1.

Interms of medical specialities, most of the contributions were from the fields of "Virology" for SARS, "Infectious Diseases" for MERS and "Medicine General Internal” for COVID-19. The biggest contribution for publications wasfrom People's Republic of China (PRC) for SARS and COVID-19 and was from The United States of America (USA) for MERS. The most of the type of publications was "article" for SARS and MERS and was "editorial material" for COVID-19. Regarding numbers of authors' contributions Yuen KY, Memish ZA and Mahase E were ranked in first rows for SARS, MERS and COVID-19 respectively. Journals that published the most papers related 
Table 1. Comparison of scientific papers published in SCI-E related to SARS, MERS and COVID-19 in overall and earlyphase of pandemics

\begin{tabular}{|c|c|c|c|}
\hline & $\begin{array}{l}2003 \\
\text { Severe Acute Respiratory Syndrome } \\
\text { (SARS-CoV) }\end{array}$ & $\begin{array}{l}2012 \\
\text { Middle East Respiratory Syndrome } \\
\text { (MERS-CoV) }\end{array}$ & $\begin{array}{l}2019 \\
\text { Covid-19 } \\
\text { (SARS-CoV-2) }\end{array}$ \\
\hline Terms used for analysis & $\begin{array}{l}\text { "SARS" } \\
\text { "SARS-CoV" } \\
\text { "Severe Acute Respiratory Syndrome" }\end{array}$ & $\begin{array}{l}\text { "MERS" } \\
\text { "MERS-CoV" } \\
\text { "Middle East Respiratory Syndrome" } \\
\text { "HCoV-EMC" }\end{array}$ & $\begin{array}{l}\text { "Covid-19" } \\
\text { "SARS-CoV-2" } \\
\text { "2019-nCoV" } \\
\text { "Coronavirus disease 19" } \\
\text { "2019 novel coronavirus" }\end{array}$ \\
\hline Total number of publications & 3690 & 1517 & 730 \\
\hline Outbreak date & November 2002 & June 2012 & Late December 2019 \\
\hline $\begin{array}{l}\text { Number of publications in first } \\
4 \text { months as an early phase of } \\
\text { outbreaks }\end{array}$ & $\begin{array}{l}10 \text { papers } \\
\text { From November } 2002 \text { to March } 2003\end{array}$ & $\begin{array}{l}\text { Up to November 2012, there was no } \\
\text { publication in SCI-E journals about } \\
\text { MERS }\end{array}$ & $\begin{array}{l}730 \text { papers } \\
\text { From January } 2020 \text { to } \\
15 \text { April } 2020 \text { (Analyse date) }\end{array}$ \\
\hline Language (Top language) & English (98.42\%) & English (99.34\%) & English $(98.63 \%)$ \\
\hline Number of publications per year & Figure 1 & & \\
\hline
\end{tabular}

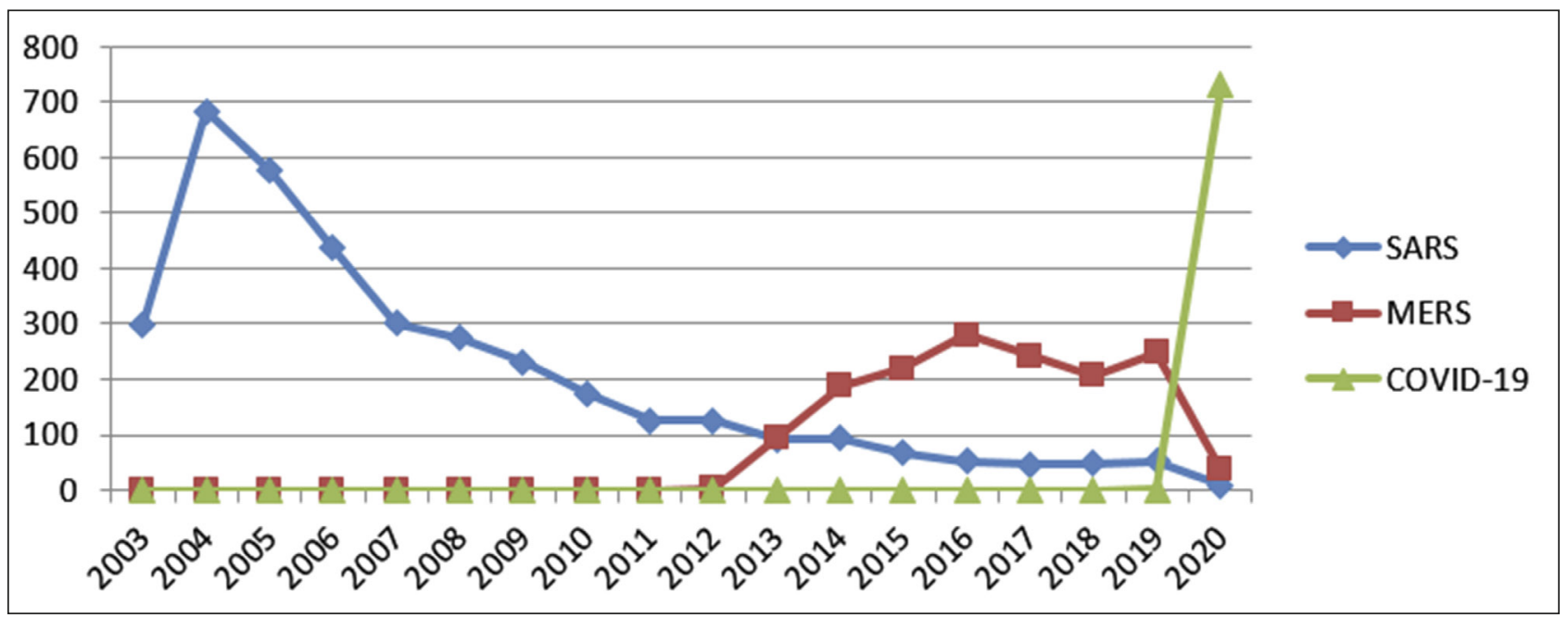

Figure 1. Number of publications per year for each outbreak.

each outbreak were "The Journal of Virology" for SARS, "Emerging Infectious Disease" for MERS and "British Medical Journal" for COVID-19 (Table 2).

The sum of total citations, the citation-to-work ratio, the citation-to-work ratio without self-citations and hindexes for these three outbreaks were reported on the Table 3. And the number of citations per year for each was showed on Figure 2.

\section{Discussion}

The largest family in the order of Nidovirales is Coronaviridae. It has two subfamilies, Letovirinae and Orthocoronavirinae ${ }^{12}$. Orthocoronavirinae subfamily consists of four genera as alpha coronavirus, beta coronavirus, gamma coronavirus and delta coronavirus. Coronaviruses mainly cause respiratory diseases in humans and enteric diseases in animals $s^{2,6,7,12,14,18}$. The latest coronavirus is belongs to a new evolutionary branch within the $\mathrm{CoV}$. It officially renamed as "SARS-CoV-2" and "2019-nCoV". The disease caused by SARS-CoV-2 was called "coronavirus disease 2019" (COVID-19) ${ }^{5,6}$. While SARS-CoV-2 shares a highly similar gene sequence of $80 \%$ and behavior pattern with SARS-CoV ${ }^{5,6,8,15}$, it show some similarities (50\%) with MERS-CoV 5,6 . Coronaviruses are spherical, enveloped, single-stranded, positivegenomic RNA viruses $1,4,7,8,11,12,14,16$. 
Table 2. Comparison of scientific contributions related to SARS, MERS and COVID-19

\begin{tabular}{|c|c|c|c|}
\hline & SARS & MERS & COVID-19 \\
\hline \multirow{5}{*}{$\begin{array}{l}\text { Web of science categories } \\
\text { (Top } 5 \text { categories) }\end{array}$} & Virology & Infectious Diseases & Medicine General Internal \\
\hline & Biochemistry Moleculer Biology & Immunology & Infectious Diseases \\
\hline & Infectious Diseases & Virology & $\begin{array}{l}\text { Radiology Nuclear Medicine } \\
\text { Medical Imaging }\end{array}$ \\
\hline & Immunology & Public Environmental Occupational Health & Critical Care Medicine \\
\hline & Microbiology & Microbiology & $\begin{array}{l}\text { Public Environmental } \\
\text { Occupational Health }\end{array}$ \\
\hline \multirow{5}{*}{$\begin{array}{l}\text { Countries contribution and percent } \\
\text { of contribution for each country } \\
\text { (Top } 5 \text { countries) }\end{array}$} & Peoples R China (39.35\%) & USA (35.33\%) & Peoples R China (33.01\%) \\
\hline & USA (29.29\%) & Saudi Arabia (24.45\%) & USA (15.61\%) \\
\hline & Taiwan $(9.51 \%)$ & Peoples R China (19.44\%) & England (11.64\%) \\
\hline & Canada $(8.67 \%)$ & South Korea (12.32\%) & Italy $(6.16 \%)$ \\
\hline & Singapore $(6.93 \%)$ & England $(7.97 \%)$ & Switzerland (4.38\%) \\
\hline \multirow{5}{*}{$\begin{array}{l}\text { Types of documentations and } \\
\text { percentages } \\
\text { (Top } 5 \text { types) }\end{array}$} & Article $(85.04 \%)$ & Article $(68.29 \%)$ & Editorial material (36.30\%) \\
\hline & Review (8.18\%) & Review $(9.55 \%)$ & Early Access (24.65\%) \\
\hline & Proceedings paper (2.98\%) & Editorial material $(7.91 \%)$ & Article $(20.95 \%)$ \\
\hline & Meeting abstract $(2.71 \%)$ & Letter $(6.06 \%)$ & Letter $(20.27 \%)$ \\
\hline & Editorial material (2.24\%) & Meeting abstract (5.20\%) & News item $(17.12 \%)$ \\
\hline \multirow{5}{*}{$\begin{array}{l}\text { Authour's contribution } \\
\text { (Top } 5 \text { authors) }\end{array}$} & Yuen $\mathrm{KY}(\mathrm{n}=83)$ & Memish ZA ( $n=90)$ & Mahase $E(n=25)$ \\
\hline & Peiris JSM ( $n=78)$ & Al-Tawfiq JA $(n=66)$ & lacobucci $G(n=18)$ \\
\hline & Chan PKS $(n=67)$ & Drosten C $(n=57)$ & Rimmer $A(n=15)$ \\
\hline & Sung JJY ( $n=61)$ & Haagmans $B L(n=46)$ & Wiwanitki V $(n=10)$ \\
\hline & Chan KH $(n=60)$ & Gerber $\mathrm{SI}(\mathrm{n}=42)$ & Yang $Y(n=9)$ \\
\hline \multirow{5}{*}{$\begin{array}{l}\text { Journals that published the papers } \\
\text { (Top } 5 \text { journals) }\end{array}$} & Journal of Virology & Emerging Infectious Diseases & BMJ British Medical Journal \\
\hline & Emerging Infectious Diseases & Journal of Virology & Lancet \\
\hline & Virology & International Journal of Infectious Diseases & Eurosurveillance \\
\hline & $\begin{array}{l}\text { Biochemical and Biophysical Research } \\
\text { Communications }\end{array}$ & Eurosurveillance & Journal of Medical Virology \\
\hline & Antiviral Research & Lancet Infectious Diseases & $\begin{array}{l}\text { Lancet Infectious Diseases, } \\
\text { Lancet Respiratory Medicine }\end{array}$ \\
\hline
\end{tabular}

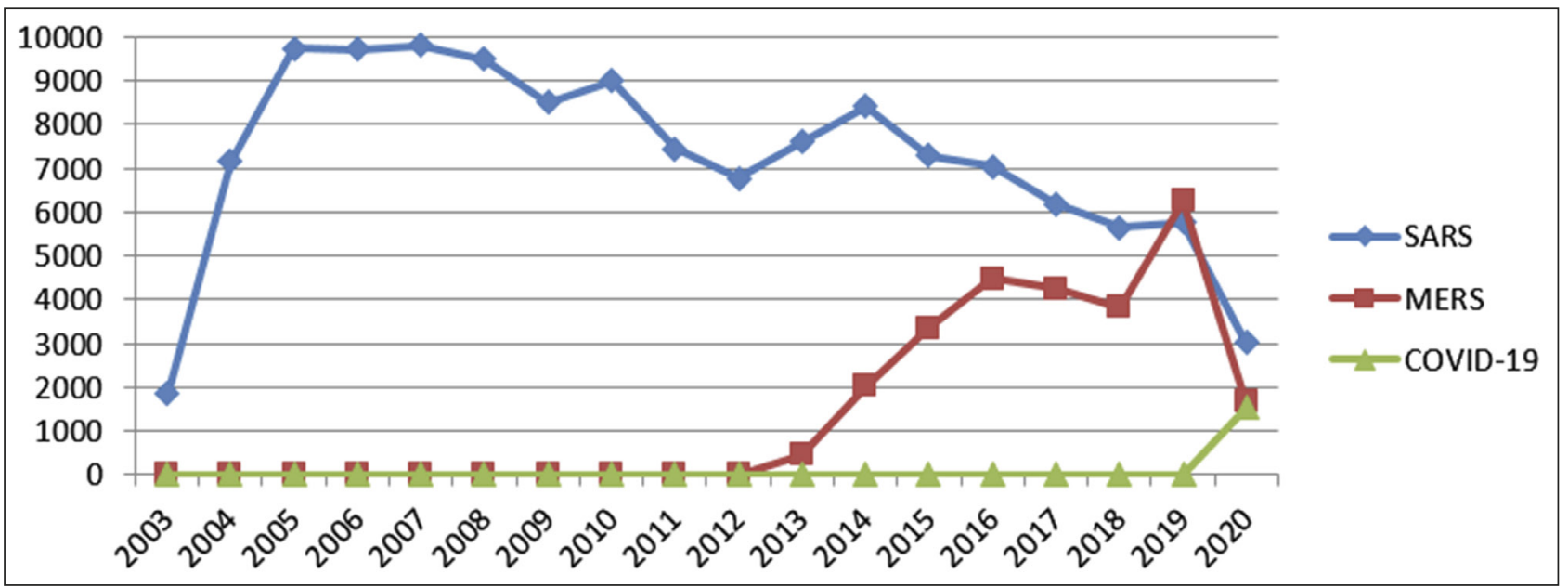

Figure 2. Number of citations per year for each outbreak. 
Table 3. Citations of outbreak's publications

\begin{tabular}{lccc}
\hline & SARS & MERS & COVID-19 \\
\hline h-index & 137 & 76 & 16 \\
Average citation per item & 35.32 & 17.36 & 2.11 \\
sum of times cited & 130.32 & 26.34 & 1539 \\
without self-citations & 83.19 & 11.34 & 830 \\
Number of citations per year & Figure 2 & & \\
\hline
\end{tabular}

The coronavirus lead to MERS was initially named as $\mathrm{HCoV}$-EMC. But all patients diagnosed with MERS have been directly or indirectly linked one of the Middle East countries. Therefore it was renamed as MERS$\mathrm{CoV}^{7}$. SARS-CoV, MERS-CoV and SARS-CoV-2 belongs to Beta coronavirus genus in the Coronaviridae family ${ }^{1,16}$. While SARS-CoV belongs to Betacoronavirus lineage $\mathrm{B}^{3,7,18}$, MERS-CoV belongs to lineage $\mathrm{C}$ of the genus Betacoronavirus $s^{3,7,12,18}$. While functional receptor is Human Angiotensin-Converting Enzyme 2 (ACE2) for SARS-CoV ${ }^{3,10,13,18}$; Dipeptidylpeptidase 4 (DPP4 or CD26) for MERS-CoV $3,13,14,18$.

In the last 50 years, many different types of coronavirus have emerged, causing a wide range of diseases. However, since the disease maintains its natural course and can limit itself in most cases; diagnosis of coronaviruses was unnecessary until the outbreaks of SARS and MERS occurred ${ }^{14,18}$. MERS-CoV transmission from human-to-human was lower than SARS-CoV ${ }^{15,19}$. But transmissibility of SARS-CoV-2 is faster than the previous outbreaks events SARS-CoV and MERS-CoV. Also SARS-CoV-2 is highly contagious as compared to SARS-CoV and MERS-CoV ${ }^{4}$. According to related reports, total number of infected cases, number of countries involved and total number of deaths were revealed higher than SARS and MERS when compared them with the same period of the outbreaks, in their first 4 months. Although, fatality rate of MERS$\mathrm{CoV}$ was higher than SARS-CoV; SARS-CoV-2 seems that it may have more fatality rate than MERS-CoV. Speed of pandemic spread also can be classified as high for COVID-19, moderate for SARS and lower for $\operatorname{MERS}^{4,7,15}$.

While the outbreak of SARS and COVID-19 were mainly found during the winter season (DecemberJanuary), the MERS was mainly found during the summer period (May-July) ${ }^{4}$. There is still a lack of a certain answer for that in the literature as well as for the question of "Why does SARS-CoV-2 appear to spread more rapidly than SARS-CoV or MERS-CoV in the human population, despite SARS-CoV and SARS-CoV-2 appear to use the same cell receptor of ACE2?"15. Probable mechanisms that can explain this high transmission that we encountered in the literature are: longer incubation time of SARS-CoV-2 ${ }^{16}$ and transmission through international air travel ${ }^{9}$. On the other hand, up to date, there is no prophylactic, therapeutic or specific treatment is currently available for $\mathrm{HCoVs}^{2,7,13,14,18}$, so treatments are only supportive ${ }^{14}$.

According to a bibliometric study for SARS that Chiu et al reported in 2004, "Bibliometric analysis of Severe Acute Respiratory Syndrome-related research in the beginning stage", although most cases are reported from China, the most broadcasts are from mainstream countries. In addition, only 1 article from China was published in SCI index journal, while mainstream countries reports were published in SCI indexed journals. They explained it in the following ways: I) While countries that reported large number of cases were focused on identification, diagnosis and treatment; mainstream countries were focused on disease control, drug and vaccine development ${ }^{20}$ II) Also non-english speaking countries may have disadvantage in publishing in SCI journals since English is lingua franca of science ${ }^{20,21}$. But according to our bibliometric results, which was conducted about 16 years after Chiu, the most SCI indexed papers were from China, the most contributed top 5 authors were from China.

According to research "Global research trends of Middle East respiratory syndrome coronavirus: a bibliometric analysis" by Zyoud in 2016, only 9 publications have been published since the beginning of the MERS epidemic, until 2013. Up to 2016, the biggest contribution for literature was from USA and Saudi Arabia. He explained commonest contribition of USA for publications as: MERS- $\mathrm{CoV}$ have been posed a global risk and the USA has played an important role in the development of international cooperation in MERS- $\mathrm{CoV}$ research and control. Other possible explanation for this was that the USA is the most prolific country for scientific research in general in previous bibliometric studies. Other countries in Asia-Pacific, such as China and South Korea, were also increased their scientific research on MERS-CoV in 2015 due to new outbreaks in their countries ${ }^{21}$. Our bibliometric results, which we conducted about 5 years after Zyoud, 
were consistent with the results of Zyoud. In our study, the biggest contributions for publications were from USA, Saudi Arabia, Peoples R China and South Korea respectively.

According to our study results, the most contribution to COVID-19 in this short early period was from China. The most probable explanation fort this was that the outbreak was first seen in Wuhan and than spread to Europe later.

While documents were mainly articles for SARS and MERS, it was editorial materials for COVID-19. Because although there was time to conduct controlled studies after SARS and MERS outbreaks; since new searches for the treatment of cases still continue for COVID-19, the publications on COVID-19 were in the form of sharing clinical information in scientific environment.

When the first early 4 months period was evaluated for each outbreak, the number of publications for COVID-19 was higher than other outbreaks. We can explain that as COVID-19 transmissibility is very high compared to SARS and MERS, it is still in the form of a global pandemic, and there is still no accepted treatment and vaccine. Also scientists may have chosen to publish their clinical experience and the effectiveness of their treatments editorially in order to reach their colleagues around the world more quickly.

"Journal of Virology" and "Emerging Infectious Diseases" journals shared first and second raw in publishing papers about SARS and MERS. "BMJ British Medical Journal" published the most papers on COVID-19. While studies about SARS and MERS werepublished in special journals, COVID-19 studies were published in general medicine journals with high impact factor ${ }^{22}$. This can be interpreted as another indicator of the sensitivity shown to COVID-19.

WoS-based bibliometric studies have some limitations and pitfalls. It is not possible to obtain articles included in SCI-E published before $1980^{23}$. And although WoS database is updated regularly, the numerical changes in results should be taken into consideration ${ }^{23,24}$. "Synonymy" and "homonymy" issues are other handicaps of $\mathrm{WoS}^{25}$. Additionally, in terms of searching, a researcher has two options in WoS; "basic" and "advanced" searches. Since these are resulted in different outcomes, it must be chosen wisely according to the aim of the study. Therefore it is advised to perform the search and the analysis by experts or by assistance of experts on the field to increase the quality of the analy$\operatorname{sis}^{26}$. In spite of all these, WoS is still considered as a gold standard for bibliometric studies ${ }^{27}$.

\section{Conclusion}

By this study, we showed that scientific contribution to COVID-19 is faster and greatful then SARS and MERS in the early phase of the outbreaks. But the pandemic potential of $\mathrm{HCoVs}$, especially SARS-CoV-2, remains a threat for public health globally. Therefore further research into the pathogenesis of $\mathrm{HCoVs}$ infections in order to fiin appropriate targets for treatment is imperative.

\section{References}

1. de Wit E, van Doremalen N, Falzarano D, Munster VJ. SARS and MERS. recent insights into emerging coronaviruses. Nat Rev Microbiol 2016;14(8):523-34.

2. Liu J, Zheng X, Tong Q, Li W, Wang B, Sutter K, Trilling M, Lu M, Dittmer U, Yang D. Overlapping and discrete aspects of the pathology and pathogenesis of the emerging human pathogenic coronaviruses SARS-CoV, MERS-CoV, and 2019-nCoV. J Med Virol 2020;92(5):491-494.

3. Song Z, Xu Y, Bao L, Zhang L, Yu P, Qu Y, Zhu H, Zhao W, Han Y, Qin C. From SARS to MERS, Thrusting Coronaviruses into the Spotlight. Viruses 2019;11(1):59.

4. Meo SA, Alhowikan AM, Al-Khlaiwi T, Meo IM, Halepoto DM, Iqbal M, Usmani AM, Hajjar W, Ahmed N. Novel coronavirus 2019-nCoV. prevalence, biological and clinical characteristics comparison with SARS-CoV and MERS-CoV. Eur Rev Med Pharmacol Sci 2020;24(4):2012-2019.

5. Lai CC, Shih TP, Ko WC, Tang HJ, Hsueh PR. Severe acute respiratory syndrome coronavirus 2(SARS-CoV-2)and coronavirus disease-2019(COVID-19): The epidemic and the challenges. Int J Antimicrob Agents 2020;55(3):105924.

6. Xu J, Zhao S, Teng T, Abdalla AE, Zhu W, Xie L, Wang Y, Guo X. Systematic Comparison of Two Animal-to-Human Transmitted Human Coronaviruses: SARS-CoV-2 and SARSCoV. Viruses 2020;12(2):244.

7. Gao H, Yao H, Yang S, li L. From SARS to MERS. evidence and speculation. Frontiers of Medicine 2016;10(4):377-382.

8. Singhal TA Review of Coronavirus Disease-2019(COVID-19). Indian J Pediatr 2020;87:281-286.

9. Lee KM, Jung K. Factors Influencing the Response to Infectious Diseases: Focusing on the Case of SARS and MERS in South Korea. Int J Environ Res Public Health 2019;16(8):1432.

10. Reperant LA, Osterhaus ADME. AIDS, Avian flu, SARS, MERS, Ebola, Zika... what next? Vaccine 2017;35(35 Pt A):4470-4474.

11. Al-Tawfiq JA, Zumla A, Memish ZA. Travel implications of emerging coronaviruses: SARS and MERS-CoV. Travel Med Infect Dis 2014;12(5):422-8. 
12. Banerjee A, Kulcsar K, Misra V, Frieman M, Mossman K. Bats and Coronaviruses. Viruses 2019;11(1):41.

13. Gretebeck LM, Subbarao K. Animal models for SARS and MERS coronaviruses. Curr Opin Virol 2015;13:123-9.

14. Fehr AR, Perlman S. Coronaviruses: an overview of their replication and pathogenesis. Methods Mol Biol 2015;1282:123.

15. Weston S, Frieman MB. COVID-19: Knowns, Unknowns, and Questions. mSphere 2020;5(2): e00203-20.

16. Jiang X, Rayner S, Luo MH. Does SARS-CoV-2 has a longer incubation period than SARS and MERS? J Med Virol 2020;92(5):476-478.

17. Coronavirus disease (COVID-19)Available at: www. who. int/ emergencies/diseases/novel-coronavirus-2019. Accessed:11 05 2021.

18. Yin Y, Wunderink RG. MERS, SARS and other coronaviruses as causes of pneumonia. Respirology 2018;23(2):130-137.

19. Brown C. MERS differs from SARS, say experts. CMAJ 2014;186(9): E303-E304.

20. Chiu WT, Huang JS, Ho YS. Bibliometric analysis of Severe Acute Respiratory Syndrome-related research in the beginning stage. Scientometrics 2004;61(1):69-77.
21. Zyoud SH. Global research trends of Middle East respiratory syndrome coronavirus: a bibliometric analysis. BMC Infect Dis 2016;16:255.

22. Zhu C 2018 Journal impact factor list (JCR 2018). Technical report 2018. Avalable at: https://www. researchgate. net/ publication/323571463_2018_Journal_Impact_Factor_ JCR_2018.

23. Bas K, Dayangac M, Yaprak O, Yuzer Y, Tokat Y. International collaboration of Turkey in liver transplantation research: a bibliometric analysis. Transplant Proc 2011;43:3796-801.

24. Bas K, Derici S, Arkan T, Yener S, Atila K. Global Practice vs. Research on Bariatric Surgery Over the Last Decade. Clin Surg 2016;1:1201.

25. Haustein S, Larivière V. The Use of Bibliometrics for Assessing Research: Possibilities, Limitations and Adverse Effects. Bibliométrie évaluation de la recherche 2015:121-139.

26. Weingart P. Impact of bibliometrics upon the science system: Inadvertent consequences? Scientometrics 2005;62:117-131.

27. Thompson DF, Walker CK. A descriptive and historical review of bibliometrics with applications to medical sciences. Pharmacotherapy 2015;35(6):551-559. 